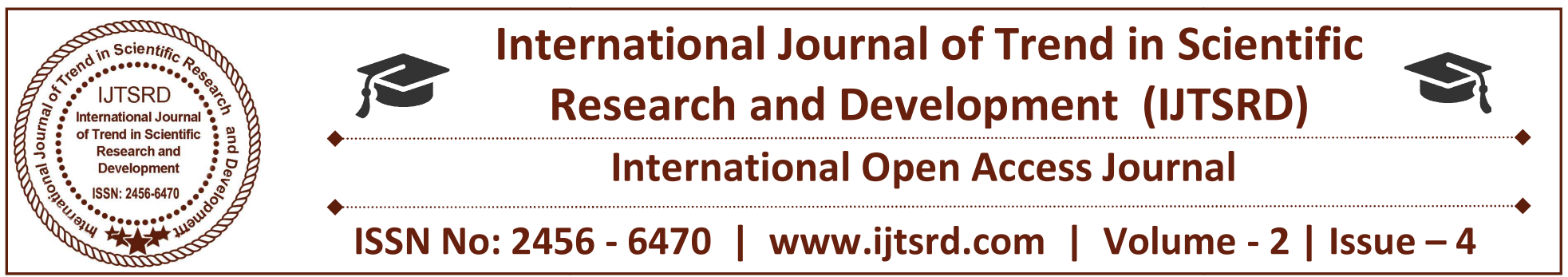

\title{
Corporate Leadership: A Study of Interpersonal Skills in Growing in the Corporate World
}

\author{
Prof. Dr. Satya Subrahmanyam \\ Head and Managing Partner \\ Vignan Institute of Technology and Management
}

\section{INTRODUCTION}

Put in simple terms, now more than ever, people spend a major portion of their working day relating to and interacting with others. For instance, corporate leaders tasked with helping their employees and coworkers accomplish corporate goals must possess the necessary people skills to motivate and facilitate optimal employee performance (Boyatzis, 1982). Hayes (2002) suggested that a distinguishing factor between the successful and unsuccessful leaders is his or her level of interpersonal competence. One survey of training and development professional supported this point, with over one-third of the respondents reporting that communication or interpersonal relationships skills were the most important qualities in a good boss (ASTD, 2000).

\section{BACKGROUND TO THE STUDY}

Many individuals have postulated about the origin and scope of interpersonal skills. Klein and Colleagues (2006) described the interpersonal skills label as an umbrella term that refers to a wide variety of concepts and associated terms, such as social skills, social competence, people skills, face-to-face skills, human skills and soft skills. Historically, social skill has been evaluated from two perspectives. The traitbased approach positions social skill as an enduring personality characteristic (Friedman \& MillerHerringer, 1991; Segrin, 1998) with relations to other individual-difference variables, including empathy (Nezlek, Feist, Wilson \& Plesko, 2001) and extraversion (Lieberman \& Rosenthal, 2001). The second perspective, the molecular model (Argyle \& Kendon, 1967; Hayes, 2002) views social skills as situation-specific behaviours that are partially learned, partially instinctive and subject to environmental and situational factors.

\section{STATEMENT OF THE PROBLEM}

The professed need for strong interpersonal skills in the corporate world extends to virtually every field of endeavour. A survey commissioned by Microsoft of 500 board-level executives supports the value of interpersonal skills. Of those surveyed, $61 \%$ said that interpersonal and team working skills were more important than information technology skills (Espiner, 2007). Microsoft Chairman Bill Gates added communication skills and the ability to work well with different types of people are very important (Espiner, 2007). No doubt, the increased importance of these skills has provided the impetus for vast amounts of spending on the interpersonal skills training program in order to improve these critical skills.

The increasingly multinational nature of corporations today provides further impetus for understanding interpersonal skills. Multinational corporate are constantly focused on the development and implementation of global leadership strategies (Caligiuri et al., 2001). Ne strategy popular with corporate is to send expatriate managers and executives on overseas assignments to manage the operations of a foreign subsidiary (Caliguiri et al., 2001). Without question, these expatriate executives are doomed to fail if they do not have the interpersonal and cross-cultural skills necessary to interact in these foreign settings. In fact, it has been estimated that up to $40 \%$ of expatriate employees return early from their assignments - a reality that is 
very costly for the corporate (Black \& Mendenhall, 1990).

\section{THE NEED FOR THE STUDY}

The relationship between interpersonal skills and outcomes of interest to corporate is gaining increased attention among scholars. Empirically, interpersonal skills have documented relationships with important workplace outcomes, including task performance, job dedication, interpersonal facilitation and overall performance (Ferris, Witt \& Hochwater, 2001). Although always important, the rapid expansion of the service industry has enhanced the need for interpersonal skills among both service centre managers and front-line, customer-facing employees. It is a fact that as the service sector in the overall economy has continued to expand, service industry employees have become the fastest growing segment of the workforce. Employees who perform serviceoriented work must be able to execute behaviours related to the interpersonal nature of job performance.

Hackman (1987) suggested that a well-designed (work) group has four characteristics. The first two characteristics simply require that, when forming teams, the right number of people is brought together and that they must possess the requisite task skills. The third characteristic is most relevant to the current research and states that effective teams are composed of individuals with interpersonal skills as well as task skills. The interpersonal skills, Hackman argues, are what allow the team to use their collective task skills. Moreover, it is suggested that the importance of interpersonal skills is especially apparent in diverse teams-teams that may be characterised by diversity in demographics, values, knowledge or skills (Hackman, 1987).

\section{THE SIGNIFICANCE OF THE STUDY}

Existing literature in the domain of job performance is also informatics to the discussion of interpersonal skills and there are many models of job performance in the corporate leadership literature (Campbell, McCloy, Oppler \& Sager, 1993). These and other models have identified relevant aspects of job performance that are interpersonal in nature. In general, these models are quite comprehensive, capturing those elements of performance that are important for all jobs. However, the models usually fail to capture interpersonal skills performance at a finite level-a level that would allow for the design of a valid selection, assessment or training system
(Carpenter et al., 2005). This is one area where the current research article can provide a unique contribution.

\section{RESEARCH QUESTIONS}

The study examined the following research questions:

1. What does a corporate leader need to communicate in order to be effectively?

2. In which way is a corporate leader able to use the communication skills?

\section{HYPOTHESIS}

$\mathrm{H}_{\mathrm{o}}$ : The necessity of interpersonal skills is not growing in the corporate world in the era of post globalisation.

$\mathrm{H}_{1}$ : The necessity of interpersonal skills is growing in the corporate world in the era of post globalisation.

\section{LITERATURE REVIEW}

Effective interpersonal skills are building blocks that competent communicators can use to provide clarity and precision in messages, solve problems collaboratively | and demonstrate a calm and supportive demeanour with mutual respect and an authentic understanding of role as a corporate leader (Ceri-Booms, 2010; Minter, 2010). Interpersonal skills are a key social concern because without these soft skills being effectively applied by a company's employees, customers may not receive consistent and reliable customer service (Lovett \& Jones, 2008) and corporate may become a breeding ground for mistrust and intergroup conflict (Hersey, Blanchard \& Johnson, 2001). Interpersonal skills are a strong predictor of business and professional success (Kraiger \& Kirkpatrick, 2010) as well as an indicator of a decrease in organisational success and problem solving (Hersey, Blanchard \& Johnson, 2001). Scholars have indicated a shortage of interpersonal skills in the work setting (Hagemann, 2009) and the necessity for leaders to know both technical and interpersonal skills to achieve performance goals (Mitchell, Skinner \& White, 2010).

Interpersonal skills, which are applicable for every employee, consist of information exchange, communication, diplomacy, conflict resolution, problem-solving, the motivation of others, teamwork and influence (Aldag \& Kuzuhara, 2002). Additional skills include planning, goal setting, change management, stress management, time management and delegation (Aldag \& Kuzuhara, 2002; Bantu- 
Gomez \& Rohrer, 2011). Interpersonal skills also include self - disclosure and listening, which are essential in superior and subordinate relationships. Corporate leaders practising these interpersonal skills will foster a valued and supportive environment of commitment, trust, respect, transparency and collaborative decision making (Bambacas \& Patrickson, 2008; Nayan, Shafie, Mansor, Maesin \& Osman, 2010).

In a nationwide survey pole of 150 executives in the late $1980 \mathrm{~s}, 11 \%$ of the executives said the skills most lacking in job candidates were interpersonal skills (Boles \& Sonoo, 1997). In a 1990 study by the business organisation, $88 \%$ of senior-level managers exhibited social or interpersonal skills (Boles \& Sonoo, 1997). Results from a 2005 poll of 330 employees conducted by University of Phoenix officials showed $96 \%$ of the responding executives rated attitude, communication and interpersonal skills as the most valuable employee traits (Cline, 2005). The results of a survey conducted on human resources professionals and performance professionals by Business Performance Management Forum in 2007, showed that the top three most valued competencies in organisations were leadership, technical knowledge and people skills (Kraiger \& Kirkpatrick, 2010).

In a 2010 study, Gitsham and Peters from the Ashridge Business School in the UK determined the type of skills leaders will need (Developing Business Skills for the $21^{\text {st }}$ Century, 2009). In the Gitsham and Peters study, $75 \%$ of respondents reported leaders needed to know how to engage in dialogue to build partnerships with key internal and external stakeholders. The information about leaders engaging in dialogue to build partnerships with key internal stakeholders has an emphasis on the purpose of leaders building employee and manager relationships to achieve organisational performance goals (DI Pofi, 2002; O’Toole \& Bennis, 2009).

\section{INTERPERSONAL SKILLS IN THE CORPORATE LEADERSHIP}

The value corporate leaders place on interpersonal skills becomes evident in employee and manager relationships, which have an impact on organisational performance. Bolt and Hagemann (2009) described four signs that were an indication when a future leader was experiencing trouble. These signs included the shortage of communication, engagement, personal issues, outside stressors, lack of follow through and maturity issues (Bolt \& Hagemann, 2009). When the leader no longer called to stay in touch with team members this failure to stay in touch has been an indicator of a decrease in commitment, engagement and passion (Bolt \& Hagemann, 2009). Other signs of trouble included when a leader has poor selfcontrol, lack of self-awareness and low or underdeveloped emotional intelligence (Bolt \& Hagemann, 2009; Liu, 2010).

Laurer (2007) suggested five traits for managers to avoid, which can negatively affect employee and manager relationships and organisational performance. They are...

The first trait is for a leader not to humiliate staff members in front of other individuals.

Second, leaders should not make fast decisions, even though the decisive action is normal behaviour today. Instead, a leader needs to assess the situation thoroughly before making crucial decisions to avoid making wrong decisions and causing havoc on a company.

Third, the leader needs to set realistic deadlines to keep quality and staff morale from suffering.

The fourth trait is for a leader not to interfere with subordinates' personal time outside the office. The leader needs to demonstrate respect for team members' lives away from the workplace.

Finally, perception becomes reality in the workplace. In other words, if leaders frequently favour one worker over another, other employees may perceive the leader not treating everyone equally.

Leaders are responsible for creating a culture of adaptability in which all employees are responsible and empowered to seem innovative answers to existing and future organisational threats and opportunities (Wu, Wang \& Tsai, 2010; Ismil, Mohamed, Sulaiman, Mohamed \& Yusuf, 2011). Leaders demonstrate their ability to lead when problems and challenges are part of the situation rather than when the organisation is experiencing growth or success (Erkutlu, 2008; Nico \& Coetzee, 2009). Specifically, effective corporate leadership becomes necessary to businesses and communities when people have to change their way of doing business according to current structures, procedures and processes (Erkutlu, 2008; Nico \& Coetzee, 2009; Babcock-Roberson \& Strickland, 2010).

To engage in adaptive leadership leaders must engage 
people in facing challenging realities and changing some priorities, attitudes and behaviours to survive and thrive in a constantly evolving setting (McLaurin \& Amri, 2008; Hickman, 2010). Leaders mobilize people to meet immediate challenges and generate cultural norms and leaders enable people to meet ongoing, adaptive challenges (McLaurin \& Amri, 2008; Hickman, 2010). The application of interpersonal skills in employee and manager relationships can have a positive impact on organisational performance (Lovett \& Jones, 2008). A leader willingly learns and retools to think and operate in new ways, experimenting with new ideas and sharing the responsibilities with stakeholders, who have an interest in the outcome (McLaurin \& Amri, 2008; Hickman, 2010).

Communication with stakeholders is important for an explanation for changes and how the corporate leaders seek to move forward with these changes (Ahmed, Shields, White \& Wilbert, 2010). If the news conveyed by a leader is unfavourable, people will appreciate an open and honest leader (Coates, 2010). In other words, leaders communicate with stakeholders by explaining why there are changes and how the organisation leaders seek to move forward with the new changes (Callahan, 2008). Additionally, leaders convey the roles stakeholders will play in the changes process as well as offer words of affirmation, encouragement and hope (De Vries, Bakker-Pieper \& Oostenveld, 2010).

Team members making vital decisions facilitate open discussions to hear everyone's ideas. The team leader creates an open communication process by clearly stating the members' roles, including shared leadership, establishing key outside relationships and including a broad team of players from diverse backgrounds (Nico \& Coetzee, 2009). Periodically, the leader and team members stop to examine how well the team members are functioning and the leaders and team members explore opportunities to improve effectiveness (Parker, 2008; Neufield, Wan \& Fang, 2010). Leaders share with all team members to provide each person adequate knowledge and understanding about the task of making informed decisions (Dixon, 2009; Hickman, 2010; Reed, 2011).

Trust is an important interpersonal skill for a leader in building successful employee and management relationships (Katz, 2003). Takash (2009) sought to explain why the development of strong relationships and positive behaviours is a long process; however, the development of strong relationships and positive behaviours become part of longer - lasting positive results. An individual who becomes a partner and not an order taker has taken the first steps toward building long-standing relationships no matter what status the person possesses (Takash, 2009). Takash (2009) explored how individuals can build trust in others, create better and stronger relationships with honesty, openness and listen to colleagues, management and customers.

Interpreting Verbal and Nonverbal Communication Behaviours as Corporate Leaders An individual who has mastered interpersonal skills has the ability to interpret verbal and nonverbal communication behaviours and the use of emotions by other individuals (Verderber, Verderber \& Fink, 2010). According to Allinson, Armstrong \& Hayes (2001), intuitive leaders may be less dominating and more nurturing than their analytic colleagues. They are more liked and respected by analytic members than analytic leaders are by intuitive members.

Leaders demonstrating technical competence and theoretical knowledge have not been doing well; instead, the leader must have the ability to interpret emotional and visual cues from other individuals (Cline, 2005; Anand \& Udaya Suriyan, 2010). Emotional intelligence involves interpersonal skills and is useful to a leader in their understanding of emotional cues (Katz, 2003; Anand \& Udaya Suriyan, 2010). Jarik Conrad (2009) discussed taking four steps for improving emotional intelligence (EI) in a corporate organisation, which consisted of...

In corporate EI into hiring processes

Assess the EI of leaders and future leaders

Ensure performance appraisals consider how the job is done

$>$ Make emotional intelligence a cornerstone of succession planning.

\section{METHODOLOGY}

There are two principal research paradigms that can be used in business research, namely - the positivistic and a phenomenological / interpretivism paradigm. According to Bryman and Bell (2007), positivism is an epistemological position that advocates the application of the methods of the natural sciences to the study of social reality and beyond. The role of positivism as stated by Anderson (2004) resides in 
searching for facts in terms of clarifying the relationship between variables before identifying a data collection pattern through statistical approaches as followed in quantitative research procedures. According to Collis and Hussey (2003), the positivistic approach concentrates on facts and the causes of social events, paying modest respect to the subjective state of the individual.

The quantitative research is built on a numerical measurement of specific characteristics related to a phenomenon. Quantitative approaches employ deductive logic, moving from the general to the specific. The tools used to carry out quantitative research tend to be surveys and questionnaires (Coombes, 2001). It is a very structured approach and is most often focused on objectivity, generalisability and reliability (Collis \& Hussey, 2003). The key advantage of the quantitative approach, therefore, is that it is based on fact and reliable data that enables researchers to generalize their findings to the population from which the sample has been drawn.

A non-experimental research design is an appropriate approach to determine if a specific treatment (Interpersonal skills of a corporate leader) influences an outcome (corporate leadership skills and effectiveness of the corporate) using a sample that is not randomly assigned to a treatment or comparator group (Creswell, 2014).

A questionnaire according to Collis and Hussey (2003) can be used to gather data when the issues which arise are likely to be confidential and sensitive and give respondents more time to consider their answers. The questionnaire survey, as defined by McDaniel and Gates (2002) is comprised of a set of questions designed to generate the evidence necessary to accomplish the objectives of the research study. It is a method of getting answers to the research questions based on designing specific questions to be answered by the research participants (Robson, 2002). Questionnaires as a survey method may be viewed as a comparatively simple and uncomplicated means of examining participants' attitudes, values, beliefs and motives. When the survey includes sensitive issues, a questionnaire affords a high level of confidentiality and anonymity (Robson, 2002).
The questionnaire consisted of five close-ended questions with an open-ended section at the end of the questionnaire for participants to add any further comments about their perception of the interpersonal skills. The response scales took the form of the Likert Scale. The Likert scale is one of the most widely used response scales in research and is used to evaluate behaviour, attitude or another phenomenon on a continuum. Rating scales simplify and more easily quantify peoples' behaviours or attitudes (Leedy \& Ormrod, 2005). A neutral response option has not been given which might prove a bit disastrous if the majority of the respondents decide to choose this, thus posing a danger of not being able to conduct an optimal evaluation.

The sample size is a significant characteristic of any empirical study in which the goal is to make assumptions about a population based on a sample. Indeed, the sample size used in the study was determined based on the data collection figures and the need to obtain sufficient statistical power (Saunders et al., 2009). Saunders et al. added that the larger the sample size, lower the likely error in generalizing to the population.

The survey was distributed to a purposeful sample of 300 participants includes corporate leaders from a different spectrum, represents different areas of specialization and comprises different sectors. Statisticians contend that as a sample size increases, variability (i.e., effort variance) decreases and power increases. As power increases to detect a false null hypothesis, there is an increased risk of falsely rejecting a true null hypothesis.

\section{ANALYSIS}

The survey asked a series of questions in order to establish whether there is a relationship between interpersonal skills of a corporate leader and the effectiveness of the corporate functioning. And the focus of the research and the survey is to find out whether the prominences of interpersonal skills growing in the corporate world. This section provides a summary of the information that was collected through a questionnaire. The following tables and figures provide a snapshot of interpersonal skills of a corporate leader. 
Table 1: Impromptu Speeches

\begin{tabular}{|c|l|l|l|l|l|l|l|}
\hline \multirow{2}{*}{} & \multicolumn{2}{|c|}{ Indicator } & \multicolumn{3}{c|}{ Agn-Agree } & \multicolumn{3}{c|}{ Agree } \\
\cline { 3 - 8 } & & $\begin{array}{l}\text { Strongly } \\
\text { Disagree }\end{array}$ & Dis-Agree & Total & Agree & Strongly Agree & Total \\
\hline 1 & $\begin{array}{l}\text { In your opinion, a leader is good } \\
\text { at making impromptu speeches. }\end{array}$ & $\begin{array}{l}48 \\
(16)\end{array}$ & $\begin{array}{l}78 \\
(26)\end{array}$ & $\begin{array}{l}126 \\
(42)\end{array}$ & $\begin{array}{l}78 \\
(26)\end{array}$ & $\begin{array}{l}96 \\
(32)\end{array}$ & 174 \\
\hline
\end{tabular}

The survey respondents were asked whether a positively that a corporate leader should be able to corporate leader is good at making impromptu make impromptu speeches.

speeches. Around $58 \%$ of respondents responded

Figure 1: Impromptu Speeches

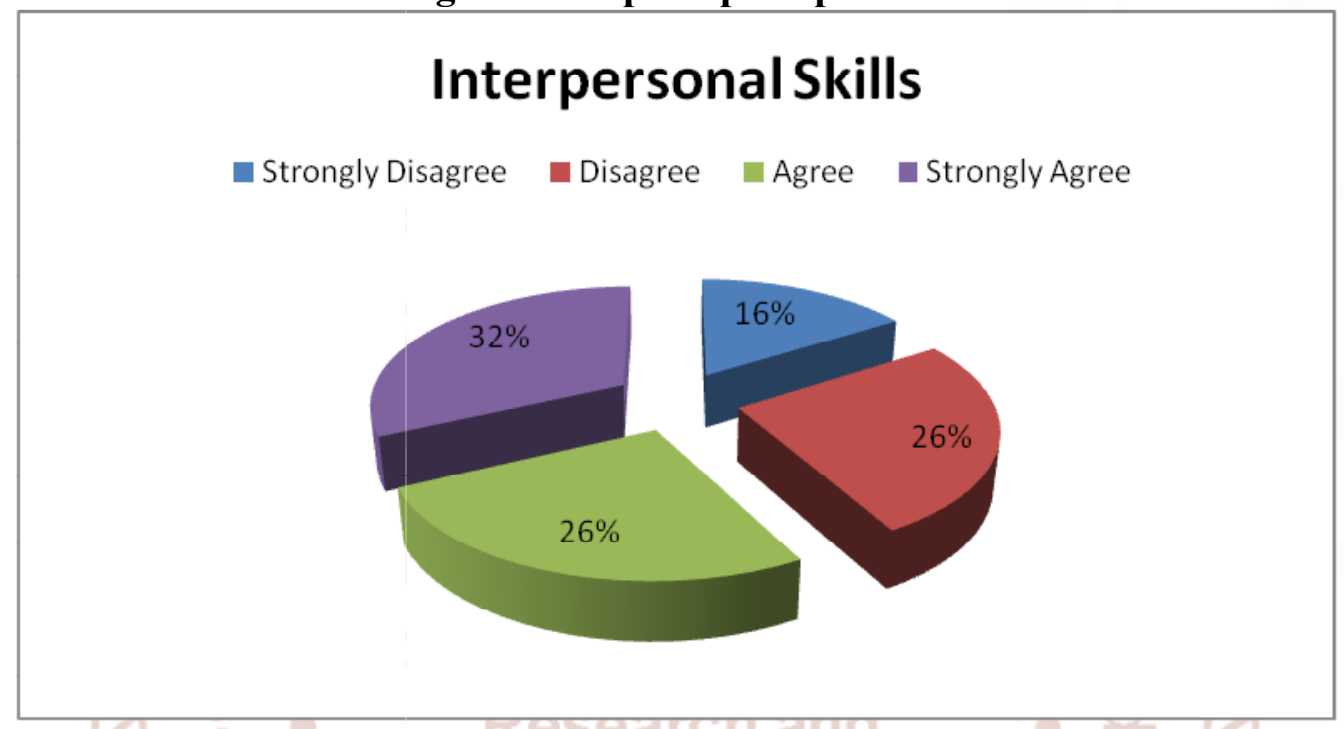

Table 2: Building Relationships

\begin{tabular}{|l|l|l|l|l|l|l|l|}
\hline \multirow{2}{*}{} & \multicolumn{2}{|c|}{ Indicator } & \multicolumn{3}{c|}{ Agree } \\
\cline { 3 - 8 } & $\begin{array}{l}\text { Strongly } \\
\text { Disagree }\end{array}$ & Dis-Agree & Total & Agree & Strongly Agree & Total \\
\hline 2 & $\begin{array}{l}\text { In your opinion, a leader generally } \\
\text { builds solid relationships with those } \\
\text { working along. }\end{array}$ & $\begin{array}{l}45 \\
(15)\end{array}$ & $\begin{array}{l}75 \\
(25)\end{array}$ & $\begin{array}{l}120 \\
(40)\end{array}$ & $\begin{array}{l}60 \\
(20)\end{array}$ & $\begin{array}{l}120 \\
(40)\end{array}$ & $\begin{array}{l}180 \\
(60)\end{array}$ \\
\hline
\end{tabular}

The survey respondents were asked whether a corporate leader should be able to build and maintain corporate leader should generally builds solid solid relationships with those working along with relationships with those working along. As high as him/her.

$60 \%$ of the respondents agreed positively that a 
Figure 2: Building Relationships

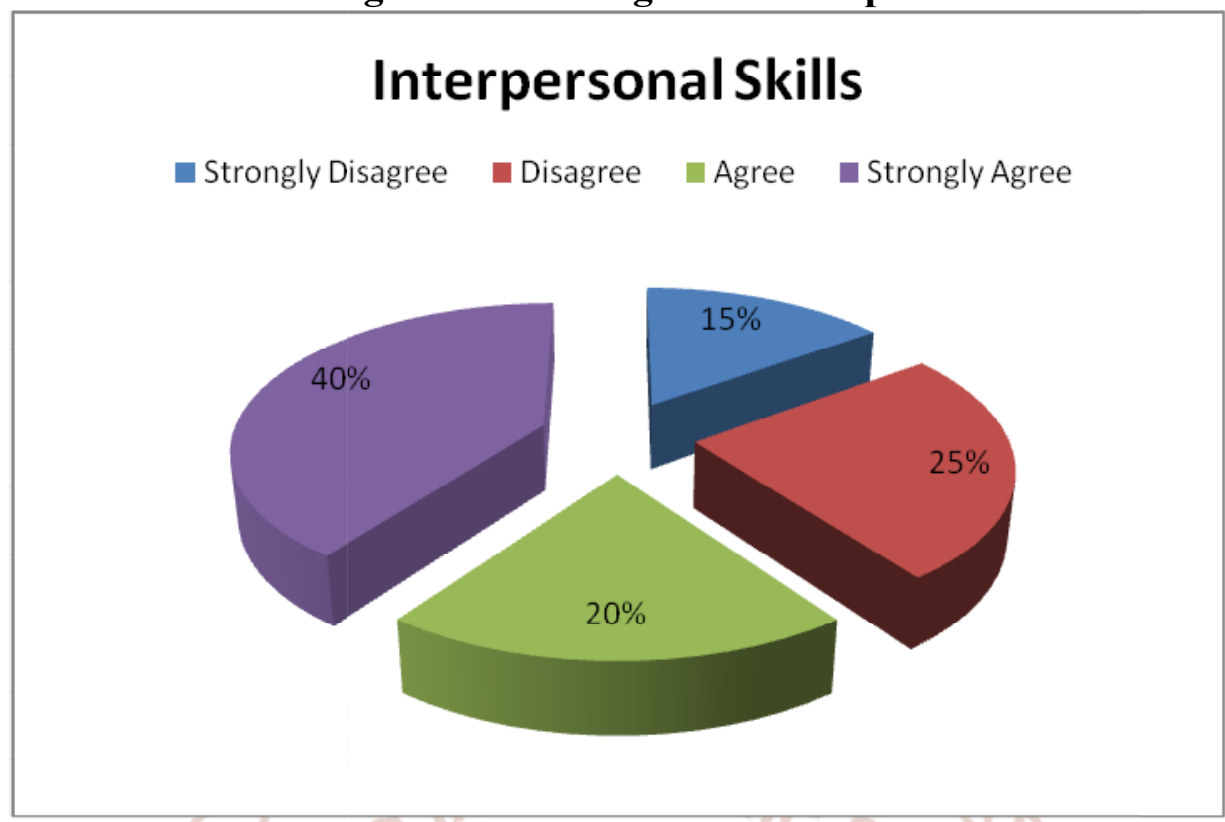

Table 3: Optimising Non-verbal Communications

\begin{tabular}{|c|c|c|c|c|c|c|c|}
\hline & \multirow[t]{2}{*}{ Indicator } & \multicolumn{3}{|c|}{ Non-Agree } & \multicolumn{3}{|c|}{ Agree } \\
\hline & & $\begin{array}{l}\text { Strongly } \\
\text { Disagree }\end{array}$ & Dis-Agree & Total & Agree & $\begin{array}{l}\text { Strongly } \\
\text { Agree }\end{array}$ & Total \\
\hline 3 & $\begin{array}{l}\text { In your opinion, a leader understands } \\
\text { and optimizes non-verbal } \\
\text { communications. }\end{array}$ & $\begin{array}{l}30 \\
(10) \\
\text { nevea }\end{array}$ & $\begin{array}{l}84 \\
(28) \text { and } \\
\text { inment }\end{array}$ & $\begin{array}{l}114 \\
(38)\end{array}$ & 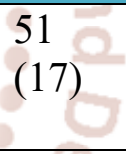 & $\begin{array}{l}135 \\
(45)\end{array}$ & $\begin{array}{l}186 \\
(62)\end{array}$ \\
\hline
\end{tabular}

The survey respondents were asked whether a good as $62 \%$ of respondents agreed positively that a corporate leader should be able to understand and corporate leader should understand and use optimally optimise the usage of non-verbal communication. As the usage of non-verbal communication gestures.

Figure 3: Optimising Non-verbal Communications

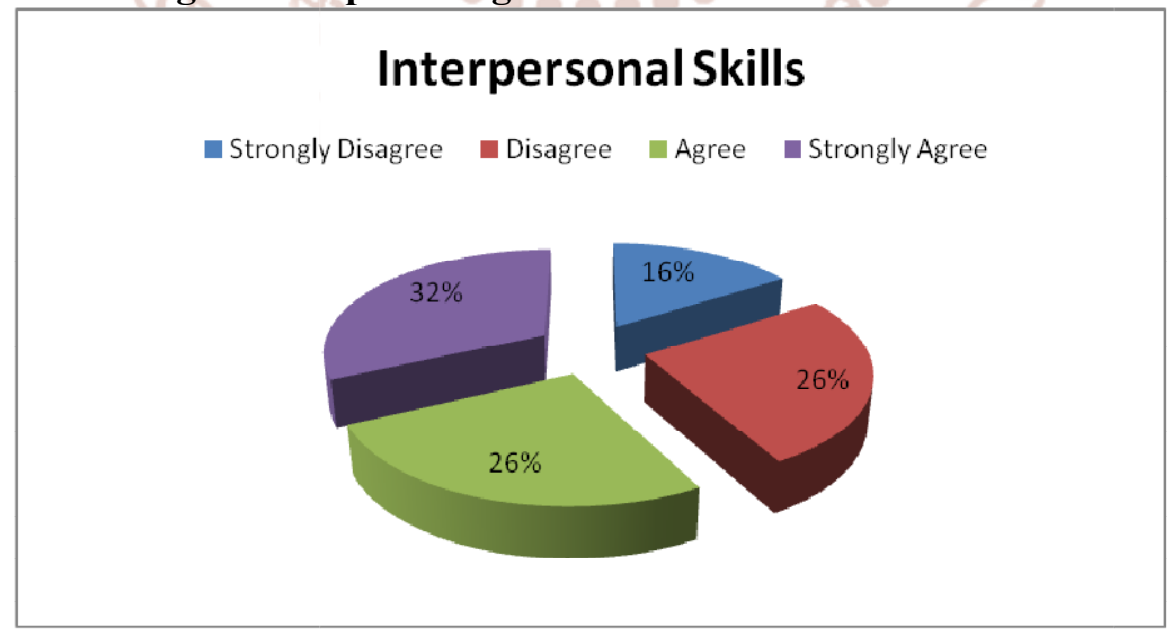


Table 4: Collaborative Skills

\begin{tabular}{|c|l|l|l|l|l|l|l|}
\hline \multirow{2}{*}{ Indicator } & \multicolumn{3}{c|}{ Non-Agree } & \multicolumn{3}{c|}{ Agree } \\
\cline { 3 - 8 } & & $\begin{array}{l}\text { Strongly } \\
\text { Disagree }\end{array}$ & Dis-Agree & Total & Agree & Strongly Agree & Total \\
\hline \multirow{2}{*}{4} & $\begin{array}{l}\text { In your opinion, a leader cooperates } \\
\text { with others to create the best results. }\end{array}$ & $\begin{array}{l}24 \\
(8)\end{array}$ & $\begin{array}{l}75 \\
(25)\end{array}$ & $\begin{array}{l}99 \\
(33)\end{array}$ & $\begin{array}{l}66 \\
(22)\end{array}$ & $\begin{array}{l}135 \\
(45)\end{array}$ & $\begin{array}{l}201 \\
(67)\end{array}$ \\
\hline
\end{tabular}

The survey respondents were asked whether a support that a corporate leader should use cooperative corporate leader should cooperate with others to methods with fellow employees to obtain optimal create the best results for the corporate. The highest results for the corporate.

i.e. $67 \%$ of the respondents reacted positively to

Table 4: Collaborative Skills

\section{Interpersonal Skills}

¿ Strongly Disagree $\quad$ Disagree $\quad$ Agree $\quad$ Strongly Agree

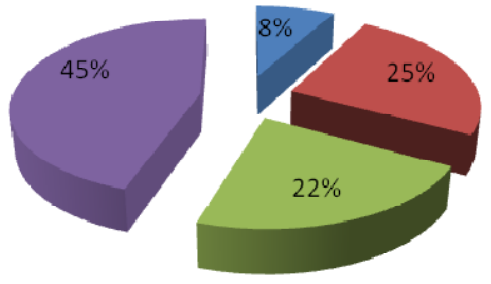

Table 5: Respecting Dignity and Rights

\begin{tabular}{|l|l|l|l|l|l|l|l|}
\hline \multirow{2}{*}{ Indicator } & \multicolumn{3}{c|}{ Non-Agree } & \multicolumn{3}{c|}{ Agree } \\
\cline { 3 - 8 } & $\begin{array}{l}\text { Strongly } \\
\text { Disagree }\end{array}$ & Dis-Agree & Total & Agree & Strongly Agree & Total \\
\hline 5 & $\begin{array}{l}\text { In your opinion, a leader respects the } \\
\text { dignity and rights of others. }\end{array}$ & $\begin{array}{l}30 \\
(10)\end{array}$ & $\begin{array}{l}96 \\
(32)\end{array}$ & $\begin{array}{l}126 \\
(42)\end{array}$ & $\begin{array}{l}60 \\
(20)\end{array}$ & $\begin{array}{l}114 \\
(38)\end{array}$ & 174 \\
\end{tabular}

The survey respondents were asked to respond number of respondents i.e. around 58\% agreed that a whether a corporate leader should respect the dignity corporate leader must respect the dignity and natural and natural rights of other fellow employees. A good rights of fellow beings.

Figure 5: Respecting Dignity and Rights

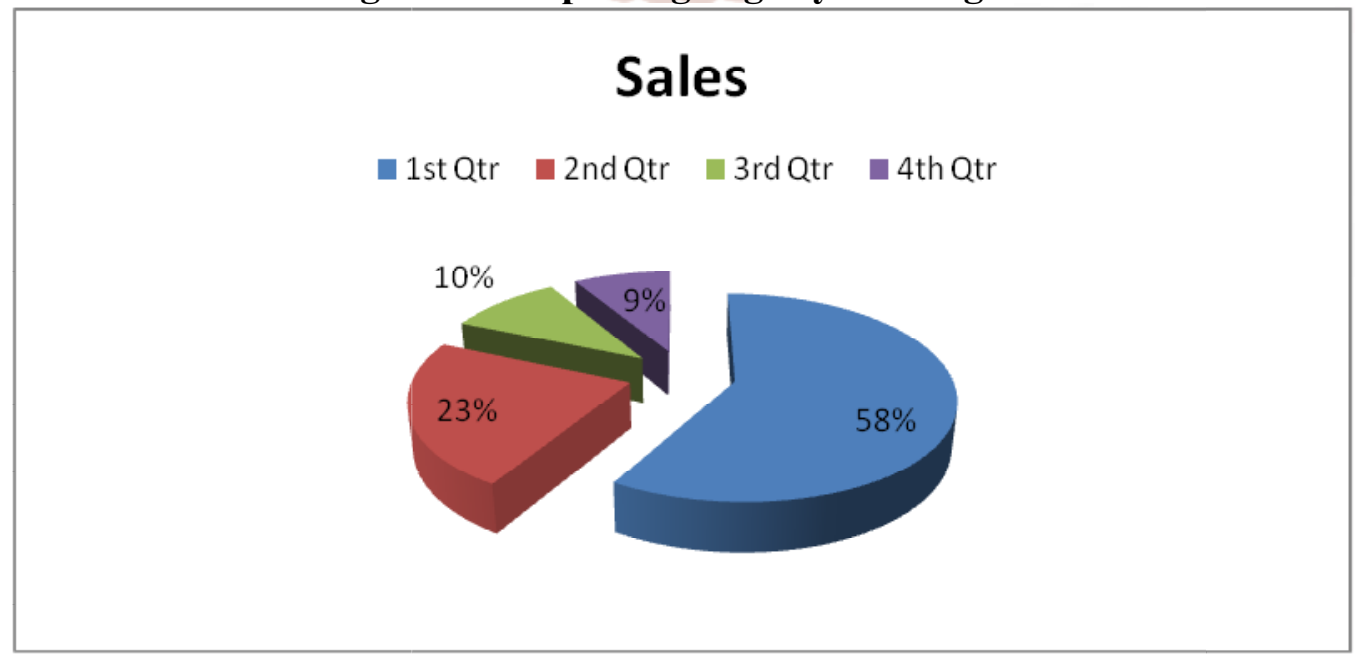


International Journal of Trend in Scientific Research and Development (IJTSRD) ISSN: 2456-6470

The Interpersonal Skills statuses of both the participants with disagrees and agree are presented in Table 6. A perusal of the table provides that the Interpersonal Skills has helped the employees to increase their level Interpersonal skills. It is found that overall 195 per cent of the total participants disagreed and 305 per cent agreed to consist different Interpersonal skills indicators i.e. impromptu speeches build solid relationships, optimizes non-verbal communications leaders, cooperates with others, respects the dignity and rights of others.

Table 6: Interpersonal Skills Comprehensive

\begin{tabular}{|c|c|c|c|c|c|c|c|}
\hline & \multirow[t]{2}{*}{ Indicator } & \multicolumn{3}{|c|}{ Non-Agree } & \multicolumn{3}{|c|}{ Agree } \\
\hline & & $\begin{array}{l}\text { Strongly } \\
\text { Disagree }\end{array}$ & $\begin{array}{c}\text { Dis- } \\
\text { Agree }\end{array}$ & Total & Agree & $\begin{array}{l}\text { Strongly } \\
\text { Agree }\end{array}$ & Total \\
\hline 1 & $\begin{array}{l}\text { In your opinion, a leader is good at making } \\
\text { impromptu speeches }\end{array}$ & $\begin{array}{l}48 \\
(16) \\
\end{array}$ & $\begin{array}{l}78 \\
(26) \\
\end{array}$ & $\begin{array}{l}126 \\
(42)\end{array}$ & $\begin{array}{l}78 \\
(26) \\
\end{array}$ & $\begin{array}{l}96 \\
(32) \\
\end{array}$ & $\begin{array}{l}174 \\
(58)\end{array}$ \\
\hline 2 & $\begin{array}{l}\text { In your opinion, a leader generally builds solid } \\
\text { relationships with those working along. }\end{array}$ & $\begin{array}{l}45 \\
(15) \\
\end{array}$ & $\begin{array}{l}75 \\
(25) \\
\end{array}$ & $\begin{array}{l}120 \\
(40)\end{array}$ & $\begin{array}{l}60 \\
(20) \\
\end{array}$ & $\begin{array}{l}120 \\
(40)\end{array}$ & $\begin{array}{l}180 \\
(60)\end{array}$ \\
\hline 3 & $\begin{array}{l}\text { In your opinion, a leader understands and } \\
\text { optimizes non-verbal communications. }\end{array}$ & $\begin{array}{l}30 \\
(10)\end{array}$ & $\begin{array}{l}84 \\
(28)\end{array}$ & $\begin{array}{l}114 \\
(38)\end{array}$ & $\begin{array}{l}51 \\
(17)\end{array}$ & $\begin{array}{l}135 \\
(45)\end{array}$ & $\begin{array}{l}186 \\
(62)\end{array}$ \\
\hline 4 & $\begin{array}{l}\text { In your opinion, a leader cooperates with others } \\
\text { to create the best results. }\end{array}$ & $\begin{array}{l}24 \odot \odot \\
(8)\end{array}$ & $\begin{array}{l}75 \\
(25) \\
\end{array}$ & $\begin{array}{l}99 \\
(33) \\
\end{array}$ & $\begin{array}{l}66 \\
(22) \\
\end{array}$ & $\begin{array}{l}135 \\
(45)\end{array}$ & $\begin{array}{l}201 \\
(67)\end{array}$ \\
\hline 5 & $\begin{array}{l}\text { In your opinion, a leader respects the dignity and } \\
\text { rights of others. }\end{array}$ & $\begin{array}{l}30 \\
(10) \\
\end{array}$ & $\begin{array}{l}96 \\
(32) \\
\end{array}$ & $\begin{array}{l}126 \\
(42)\end{array}$ & $\begin{array}{l}60 \\
(20) \\
\end{array}$ & $\begin{array}{l}114 \\
(38) \\
\end{array}$ & $\begin{array}{l}174 \\
(58)\end{array}$ \\
\hline & otal & $\begin{array}{l}177 \\
(59)\end{array}$ & $\begin{array}{l}408 \\
(136)\end{array}$ & $\begin{array}{l}585 \\
(195) \\
\end{array}$ & $\begin{array}{l}315 \\
(105) \\
\end{array}$ & $\begin{array}{l}600 \\
(200) \\
\end{array}$ & $\begin{array}{l}915 \\
(305)\end{array}$ \\
\hline
\end{tabular}

Note: The figures given in parentheses indicate percentages of participants and non-participants. The value of Chi-square $\left(\chi^{2}\right)$ is 2.8712 between participants with disagree and agree. The table values at 5 per cent with 4 degrees of freedom are 9.48 .

\section{Figure 6: Interpersonal Skills Comprehensive}

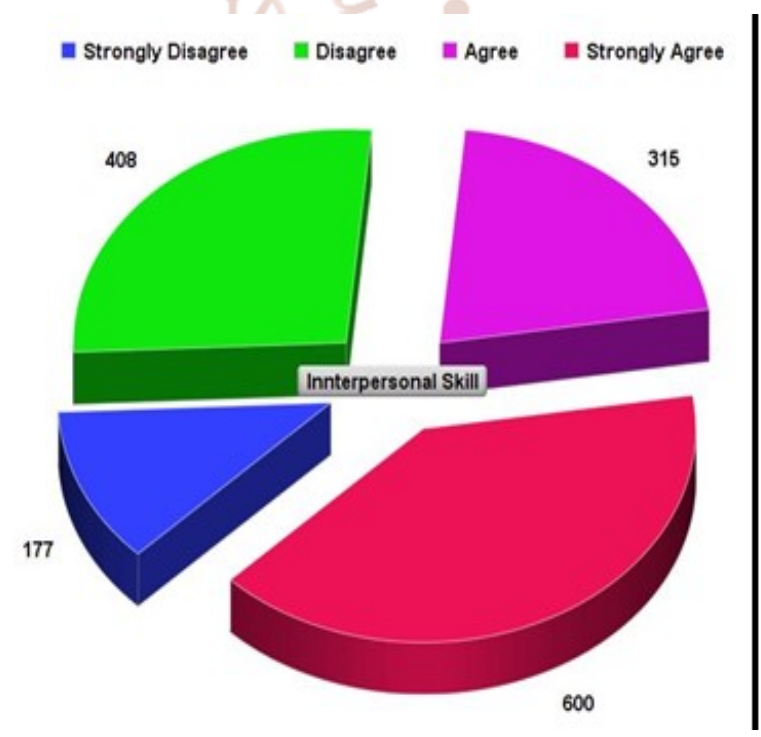

In order to measure the impact of Interpersonal skills, employees with disagreeing compared with the agreed employees. The table shows that overall 195 per cent of the total participants were disagreeing and 305 per cent was agreed consisting different relevant indicators Chi-square $(\chi 2)$ test shows the significant difference and positively accepted the hypothesis

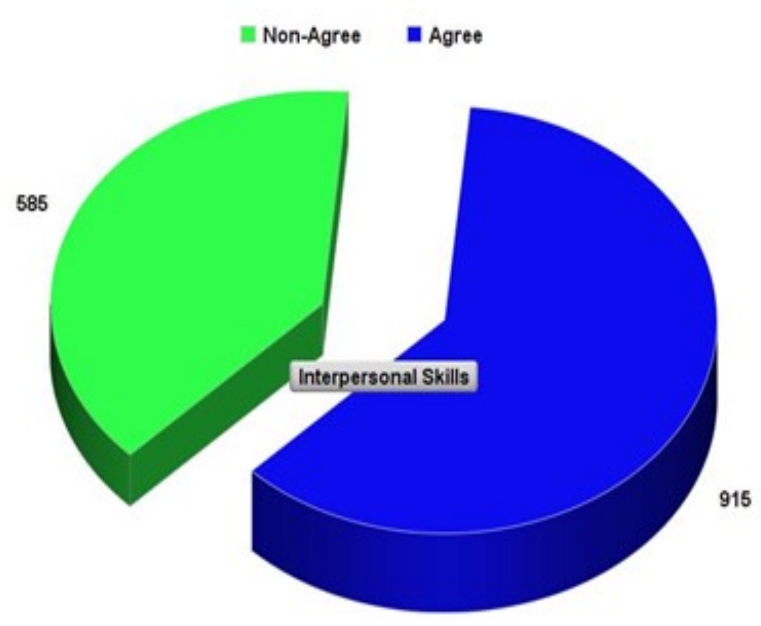

regarding the different emotional indicators i.e. impromptu speeches builds solid relationships, optimizes non-verbal communications leaders, cooperates with others, respects the dignity and rights of others with interpersonal skills and organized leadership. 


\section{CONCLUDING COMMENTS}

The research and findings presented here provide a compelling case for the importance of socio-affective competence at the corporate leadership levels of any corporate. The use of effective interpersonal skills is critical to the success of any corporate leader because of the considerable amount of time these leaders spend interacting with others. Additionally, the daily interactions that exist between a leader and corporate, team, or subordinates revolves around the management of relationships. For instance, possessing the ability to create a high degree of affinity with followers allows a leader to influence them in a positive and efficient manner.

Similarly, promoting diversity issues and valuing the opinions of individuals with different beliefs fosters an environment of support and encourages the development of innovative solutions to corporate issues. Thus, the individuals that are currently in key leadership roles and/or those that are identified as high potential should be exposed to each of the socioaffective competencies.

\section{REFERENCES}

1. Ahmed, Z., Shields, F., White, R., \& Wilbert, J. (2010). Managerial communication: The dink between frontline leadership and organizational performance. Journal of Organizational Culture, Communication, and Conflict, 14(1), 107-120. Retrieved from http://search.proquest.com.ezproxy.apollolibrary.c om $/$ docview $/ 521182139$ ? accountid $=35812$

2. Aldag, R. J., \& Kuzuhara, L. W. (2002). Organizational behaviour and management: Integrated skills approach. Cincinnati, $\mathrm{OH}$ : South-Western.

3. Allinson, C. W., Armstrong, S. J., \& Hayes, J. (2001). The effects of cognitive style on leadermember exchange: A Study of managersubordinate dyads. Journal of Occupational \& Organizational Psychology, 75(2), 201-220. Retrieved from http://web.ebscohost.com.ezproxy.apollolibrary.co $\mathrm{m} /$ ehost $/$ pdfviewer/pdfviewer ?sid $=7 \mathrm{c} 7 \mathrm{~d} 066 \mathrm{~b}$ 4706-47a3-9783-

329 eb7a39e $77 \% 40$ sessionmgr $13 \&$ vid $=12 \&$ hid $=8$

4. Anand, R., \& UdayaSuriyan, G. (2010). Emotional intelligence and its relationship with leadership practices. International Journal of
Business and Management, 5(2), 65-76. Retrieved from

http://search.proquest.com.ezproxy.apollolibrary.c om $/$ docview $/ 821696360$ ?accountid $=35812$

5. Anderson, V., 2004. Research Methods in Human Resource Management. London: CIPD.

6. Argyle, M., \& Kendon, A. (1967). The experimental analysis of social performance. Advances in Experimental Social Psychology, 3, 55-98.

7. Babcock-Roberson, M. E., \& Strickland, O. J. (2010). The relationship between charismatic leadership, work engagement, and organizational citizenship behaviours. The Journal of Psychology, 144(3), 313-326. Retrieved from http://search.proquest.com.

ezproxy.apollolibrary.com/docview/741062002?a c countid $=35812$

8. Bambacas, M., \& Patrickson, M. (2008). Interpersonal skills that enhance organizational commitment. Journal of Communication Management, 12(1), 51-72. doi: $10.1108 / 13632540810854235$

9. Bantu-Gomez, M., \& Rohrer, W. G. (2011). Teams in the organization. The Business Review, 18(1), 54-60. Retrieved from http://search.proquest.com/docview/871968527?a c countid $=35812$

10. Black, J. S., \& Mendenhall, M. E. (1990). Crosscultural training effectiveness: A review and theoretical framework for future research. Academy of Management Review, 15, 113-136.

11. Boles, M., \& Sunoo, B. P. (1997). Wanted: Leaders who can lead and write. Workforce, 76(12), 1-5. Retrieved from https://ehis.ebscohost.com/eds/detail?vid=9\&hid= $2 \&$ sid $=$ c83c6992-61 fa-4949-9c290d7827254480\%40sessionmgr12\&bdata $=\mathrm{J}$ nNpdGU9ZWRzLWxpdmU\%3d\#db=f5h\&AN=1 447

12. Bolt, J. F., \& Hagemann, B. (2009). Future leaders: Identify and develop them. Leadership Excellence, 26(10), 11. Retrieved from $\mathrm{http}: / /$ search.proquest.com. ezproxy.apollolibrary. com/docview/204624219? accountid=35812 
13. Boyatzis, R. E. (1982). The competent manager: $A$ model for effective performance. New York: John Wiley \& Sons.

14. Bryman, A. \& Bell, E., 2007. The process of quantitative research Business research methods ( $2^{\text {nd }}$ ed.). Oxford: University Press.

15. Callahan, J. (2008). The four C's of emotion: A framework for managing emotions in organizations. Organization Development Journal, 26(2), 33-38. Retrieved from http://web.ebscohost.com.ezproxy.apollolibrary.co $\mathrm{m} / \mathrm{ehost} / \mathrm{pdfviewer} / \mathrm{pdf}$ viewer?sid $=\mathrm{a} 4944 \mathrm{c} 6 \mathrm{e}-$ f4ab-4d8e-8a04

40 sessionmgr $14 \& \mathrm{vid}=5 \& \mathrm{hid}=8$

16. Caligiuri, P., Phillips, J., Lazarova, M., Tarique, I., \& Bürgi, P. (2001). The theory of met expectations applied to expatriate adjustment: The role of cross-cultural training. International Journal of Human Resource Management, 12, 357-372.

17. Campbell, J. P., McCloy, R. A., Oppler, S. H., \& Sager, C. E. (1993). A theory of performance. In N. Schmitt \& W.C. Borman (Eds.), Personnel selection. Jossey-Bass: San Francisco.

18. Carpenter, T. D., Wisecarver, M. M., Deagle, E. A. III, \& Mendini, K. G. (2005, April). Special forces interpersonal performance assessment system. Research Report 1833, Prepared for the U.S. Army Research Institute for the Behavioral and Social Sciences.

19. Ceri-Booms, M. (2010). An empirical study on transactional and authentic leaders: Exploring the mediating role of trust in the leader on organizational identification. The Business Review, 14(2), 235-243. Retrieved from $\mathrm{http}: / /$ search.proquest.

com.ezproxy.apollolibrary.com/docview/3475654 87 ? accountid $=35812$

20. Cline, S. (2005). Soft skills make the difference in the workplace. The Colorado Springs Business Journal, $1 . \quad$ Retrieved from http://web.ebscohost.com.ezproxy. apollolibrary.com/

21. Coates, B. (2010). Cracking into the panes of corporate denial. Business Renaissance, 5(3), 2346. Retrieved from

http://search.proquest.com.ezproxy.apollolibrary. com/docview/814814238? accountid=35812
22. Collis, J \& Hussey, R., 2003. Business Research. New York, Palgrave MacMillan.

23. Conrad, J. (2009). What's your EQ? Sales \& Service Excellence, 9(3), 10. Retrieved from http://web.ebscohost.com.ezproxy.apollolibrary.co $\mathrm{m} /$ ehost/pdfviewer /pdfviewer?sid=a4944c6ef4ab-4d8e-8a04-a483b70b584e\% 40sessionmgr $14 \&$ vid $=9$ \&hid $=8$

24. Creswell, J. W., 2014. Research Methods, $\left(4^{\text {th }}\right.$ ed.). Thousand Oaks, CA: Sage.

25. De Vries, R. E., Bakker-Pieper, A., \& Oostenveld, W., 2010. Leadership communication: The relations of leaders' communication styles with leadership styles, knowledge sharing and leadership outcomes. Journal of Business and Psychology, 25(3), 367-380. doi: 10.1007/s10869009-9140-2.

26. Di Pofi, J.A., 2002. Organizational diagnostics: Integrating qualitative and quantitative. Journal of Organizational Change Management, 15(2), 156168. doi: 250892111.

27. Dixon, G., 2009. Can we lead and follow? Engineering Management Journal, 21(1), 34-41. Retrieved from http://search.proquest.com.

28. Erkutlu, H., 2008. The impact of transformational leadership on organizational and leadership effectiveness: The Turkish case. The Journal of Management Development, 27(7), 708-726. doi: $10.1108 / 02621710810883616$.

29. Espiner, T. (2007). Survey: People skills valued over those for IT. CNET News, December 14.

30. Ferris, G. R., Witt, L. A., \& Hochwarter, W. A. (2001). Interaction of social skill and general mental ability on job performance and salary. Journal of Applied Psychology, 86(6), 1075-1082.

31. Friedman, H. S., \& Miller-Herringer, T. (1991). Nonverbal display of emotion in public and in private: Self-monitoring, personality, and expressive cues. Journal of Personality and Social Psychology, 61, 766-775.

32. Hackman, J. R. (1987). The design of work teams. In J. Lorsch (Ed.), Handbook of Organizational Behavior (pp. 215-342). New York: Prentice Hall.

33. Harvey, P., Martinko, M. J., \& Gardner, W. L., 2006. Promoting authentic behaviour in organizations: An attributional perspective. 
International Journal of Trend in Scientific Research and Development (IJTSRD) ISSN: 2456-6470

Journal of Leadership and Organizational Studies, 12(3), 1-11.

34. Hayes, J. (2002). Interpersonal skills at work. New York: Routledge.

35. Hersey, P., Blanchard, K. H., \& Johnson, D. E., 2001. Management of organizational behaviour: Leading human resources ( $8^{\text {th }}$ ed.). Upper Saddle River, NJ: Prentice Hall.

36. Hickman, G. R., 2010. Leading Organizations: Perspectives for a new era ( $2^{\text {nd }}$ ed.). Thousand Oaks, CA: Sage Publications.

37. Ismil, A., Mohamed, H. A., Sulaiman, A. Z., Mohamad, M. H., \& Yusuf, M. H., 2011. An empirical study of the relationship between transformational leadership, empowerment and organizational commitment. Business and Economics Research Journal, 2(1), 89-107. Retrieved from http://search.proquest.com. ezproxy.apollolibrary.com /docview/847324928 ?accountid $=35812$

38. Katz, R., 2003. The Human Side of Managing Technological Innovation ( $2^{\text {nd }}$ ed.). New York: Oxford University Press.

39. Klein, C., DeRouin, R. E., \& Salas, E. (2006). Uncovering workplace interpersonal skills: A review, framework, and research agenda. International Journal of Industrial and Organizational Psychology, 21, 79-126.

40. Kraiger, K., \& Kirkpatrick, S., 2010. N An empirical evaluation of three popular training programs to improve interpersonal skills. Journal of Psychological Issues in Organizational Culture, 1(1), 60-73. doi:10.1002/jpoc.

41. Laurer, C. S. (2007). In each other we trust. Modern Healthcare, 37(37), 20. Retrieved from http://ehis.ebscohost.com/ehost/detail?vid=10\&hi $\mathrm{d}=121 \&$ sid=bf2a13e5- dd4e-4eb9-9da8 90b93691b446\%40sessionmgr1 10\&bdata=JnNpd GU9ZWhvc3QtbG12

42. Leedy, P. D., \& Ormrod, J. E., 2005. Practical Research. Upper Saddle River, NJ: Pearson Prentice Hall.

43. Liu, C. (2010). Leadership: Qualities, skills, and efforts. Interbeing, 4(2), 19-25. Retrieved from http://search.proquest.com.ezproxy.apollolibrary.c om $/$ docview $/ 856587949$ ? accountid $=35812$
44. Lieberman, M. D., \& Rosenthal, R. (2001). Why introverts can't always tell who likes them: Multitasking and nonverbal decoding. Journal of Personality and Social Psychology, 80(2), 294310.

45. Lovett, M., \& Jones, I. (2008). Social/interpersonal skills in business. Infield, curriculum and student perspectives. Journal of Management \& Marketing Research, (1), 75-83. Retrieved from http://web.ebscohost.com.ezproxy. apollolibrary.com/ehost/detail.

46. McDaniel, C. \& Gates, R., 2002. Marketing research: the impact of the Internet. Hoboken, NJ: Wiley.

47. McLaurin, J. R., \& Amri, M. B., 2008. Developing an understanding of charismatic and transformational leadership. Allied Academics International Conference. Academy of Organizational Culture, Communications, and Conflict. Proceedings, 13(2), 15-19. Retrieved from http://search.proquest.com.ezproxy. apollolibrary.com

48. Minter, R. L. (2010). Organizational communication audits: Assessing core communication competencies within the organization. International Journal of Management and Information Systems, 14(5), 107-118. Retrieved from http://search. proquest.com.ezproxy.apollolibrary.com/docview/ 818852393 ? accountid $=35812$

49. Mitchell, G. W., Skinner, L. B., \& White, B. J., 2010. Essential soft skills for success in the twenty-first-century workforce as perceived by business educators. Delta Phi Epsilon, 52(1), 4353. Retrieved from http://search.proquest.com.

50. Nayan, S., Shafie, L. A., Mansor, M., Maesin, A., \& Osman, N., 2010. The practice of collaborative learning among lecturers in Malaysia. Management Science and Engineering, 4(2), 115123. Retrieved from http://search.proquest.com.ezproxy. apollolibrary.com.

51. Neufeld, D. J., Wan, Z., \& Fang, Y., 2010. Remote leadership, communication effectiveness and leader performance. Group Decision and Negotiation, 19(3), 227-246. doi: 10.1007/s10726008-9142-x.

52. Nezlek, J. B., Feist, G. J., Wilson, F. C., \& Plesko, R. M. (2001). Day-to-day variability in empathy 
as a function of daily events and mood. Journal of

Research in Personality, 35, 401-423.

53. Nico, M., \& Coetzee, M., 2009. Applying the Burke-Litwin model as a diagnostic framework for assessing organizational effectiveness. South African Journal of Human Resource, 7(1), 144156. doi: 10.4102/sajhrm.v7i1.177.

54. O'Toole, J., \& Bennis, W., 2009. What's needed next: A culture of candour. Harvard Business Review, 87(6), 54-61. Retrieved from http://web.ebscohost.com.

55. Parker, G., 2008. Team players and teamwork: New strategies for developing successful collaboration, completely updated and revised. San Francisco, CA: Jossey-Bass.

56. Reed, P., 2011. Developing leadership skills: Planning and reflection. The principal of Leadership, 12(4), 60-62. Retrieved from http://search.proquest.com.ezproxy.

apollolibrary.com/docview/905296942?accountid $=35812$.

57. Robson, C., 2002. Real World Research: A resource for social scientists and practitionerresearchers $\left(2^{\text {nd }}\right.$ ed.). Oxford, UK: $\odot$ Wiley Blackwell.

58. Saunders, M., Lewis, P. \& Thornhill, A., 2009. Research Methods for Business Students ( $5^{\text {th }} \mathrm{Ed}$.), London, U.K: Financial Times Prentice Hall.

59. Segrin, C. (1998). The impact of assessment procedures on the relationship between paper and pencil and behavioural indicators of social skill. Journal of Nonverbal Behavior, 22(4), 229-251.

60. Takash, J., 2009. Results through relationships: Building trust, performance, and profit through people. Business Book Summaries, 37(4), 1-10. Retrieved from http://web.ebscohost.com.ezproxy.apollolibrary.co m.

61. Verderber, K., Verderber, R., \& Fink, C., 2010. Interact $\left(12^{\text {th }}\right.$ ed.). New York, NY: Oxford University Press.

62. Wu, C., Wang, P., \& Tsai, L., 2010. The effect of organizational culture on team interaction and team effectiveness: Team leadership as a medium. Journal of International Management Studies, 5(2), 190-198. Retrieved from http://search.proquest.com.ezproxy.apollolibrary.c om. 